\title{
Obecność „Biuletynu Uniejowskiego” na rynku wydawnictw naukowych w IO. rocznicę powstania pisma
}

STRESZCZENIE | Rocznicowy - IO. tom „Biuletynu Uniejowskiego” - jest pretekstem do refleksji nad miejscem tego czasopisma na rynku wydawnictw naukowych. Artykuł stanowi swoisty raport z całego okresu działalności czasopisma. Za główny cel pracy obrano wskazanie powiązań pomiędzy badaniami publikowanymi na łamach „Biuletynu Uniejowskiego” a poszczególnymi dziedzinami i dyscyplinami naukowymi. Zrealizowano go poprzez analizę danych pochodzących z bazy Google Scholar. Mimo że niemal połowa artykułów publikowanych w „Biuletynie Uniejowskim” to teksty mieszczące się w dziedzinie nauk społecznych, to czasopismo nadal utrzymuje charakter interdyscyplinarny. Potwierdzeniem tego jest fakt, że artykuły z „Biuletynu Uniejowskiego” są cytowane w czasopismach klasyfikowanych do wielu dziedzin nauki: społecznych, ścisłych i przyrodniczych, inżynieryjno-technicznych, humanistycznych i rolniczych.

SŁOWA KL U C Z OW E | „Biuletyn Uniejowski”, Google Scholar, cytowania, parametryzacja, h-index, dziedziny naukowe, dyscypliny naukowe, wydawnictwa naukowe

Jednym z warunków racjonalnego działania jest znajomość własnych atutów i stabości - obiektywne rozeznanie rzeczywistości, na która składa się zarówno dziedzictwo przeszłości, jak i wspótczesne uwarunkowania.

Tadeusz Marszał

\footnotetext{
* Michał Kowalski, mgr, sekretarz „Biuletynu Uniejowskiego”, Uniwersytet Łódzki, Wydział Nauk Geograficznych, ul. Kopcińskiego 31, 9O-I42 Łódź; e-mail: michal.kowalski@ geo.uni.lodz.pl, https://orcid.org/oooo-000I-7082-516I
} 


\section{Wstęp}

Badania związane z ziemią uniejowską były i wciąż są wdzięcznym obszarem studiów, szczególnie dla naukowców z łódzkiego ośrodka akademickiego. Począwszy od eksploracji geograficznych ${ }^{\mathrm{I}}$, poprzez prace historyków ${ }^{2}$

I Są to m.in.: I. Kaczmarek, Ziemia Uniejowska w księgozbiorze Biblioteki Geograficznej Uniwersytetu Łódzkiego, „Biuletyn Uniejowski” 20I8, t. 7, s. I8I-I99; D. Dzieduszyńska, P. Kittel, Basen uniejowski - historia i stan badań paleogeograficznych basenu uniejowskiego w badaniach Uniwersytetu Łódzkiego, „Biuletyn Uniejowski” 20I2, t. I, 190-203; D. Stos (red.), Województwo konińskie: zarys dziejów, obraz wspótczesny, perspektywy rozwoju: monografia regionalna, Uniwersytet Łódzki, Łódź 1989; M. Koter, Środowisko geograficzne obszaru Uniejowa jako podtoże rozwoju osadnictwa i gospodarki, [w:] J. Szymczak (red.), Uniejów. Dzieje miasta, Towarzystwo Przyjaciół Uniejowa, Łódź-Uniejów 1995, s. 19-47; M. Kulesza, Rozwój przestrzenny miasta, [w:] J. Szymczak (red.), Uniejów. Dzieje miasta, Towarzystwo Przyjaciół Uniejowa, Łódź-Uniejów 1995, s. 465-490; A. Suliborski, T. Kunka, Gospodarka i warunki bytowe po II wojnie światowej, [w:] J. Szymczak (red.), Uniejów. Dzieje miasta, Towarzystwo Przyjaciół Uniejowa, Łódź-Uniejów 1995, s. 36I-365; E. Kobojek, Problem przestrzennego rozwoju miast $w$ dolinach rzecznych na przykładzie Łowicza i Uniejowa, [w:] B. Więzik (red.), Prawne, administracyjne i środowiskowe uwarunkowania zagospodarowania dolin rzecznych, Wyższa Szkoła Administracji, Bielsko-Biała 2013, s. 15-26; E. Gorczyczewska, K. Smętkiewicz, Budowa i promocja marki miejsca na przykładzie uzdrowiska termalnego Uniejów, „Studia Ekonomiczne” 2013, nr I44, s. 395-408; A. Kulawiak, T. Rachwał, K. Smętkiewicz, The Impact of Infrastructure, Industrial and Housing Investments on the Development of Local Systems Based on the Example of the Uniejow Commune in the Eódź Voivodeship (Poland), „Studies of the Industrial Geography Commission of the Polish Geographical Society” 2018, t. 32, nr 3, s. 69-97; M. Samołyk, H. Maciaszczyk, Impact of Uzdrowisko Uniejów Park (Health Resort Uniejów Park) on tourism in the neighbouring municipalities, "Geography and Tourism” 2018, t. 6, nr 2, s. 87-95; S. Kaczmarek, J. Kaczmarek, Powiazania przestrzenne, spoteczne i ekonomiczne w regionie łódzkim. Rejon Poddębice-Turek, „Acta Universitatis Lodziensis. Folia Geographica Socio-Oeconomica” 1999, nr I, s. I83-197; M. Borowska-Stefańska, Ocena ryzyka powodziowego jako element wdrażania Dyrektywy Powodziowej-przykład Uniejowa, „Problemy Rozwoju Miast” 20I4, nr 3, s. 5-II; K. Milewska-Osiecka, A. Ogrodowczyk, Warunki mieszkaniowe w matych miastach Polski ze szczególnym uwzględnieniem Uniejowa, „Acta Universitatis Lodziensis. Folia Geographica Socio-Oeconomica” 2015, nr 19, s. I29-I48; M. Frydrych, Wybrzeże klifowe zbiornika Jeziorsko i jego znaczenie $w$ badaniach geomorfologicznych i paleogeograficznych, „Acta Universitatis Lodziensis. Folia Geographica Physica” 20I3, nr I2, s. II7-I25.

2 Spośród nich warto wymienić m.in: J. Szymczak (red.), Uniejów. Dzieje miasta, Towarzystwo Przyjaciół Uniejowa, Łódź-Uniejów 1995; A. Jabłońska, Archidiakonat uniejowski w okresie staropolskim, „Biuletyn Uniejowski” 20I2, t. I, s. I4I-I56; Z. Wilk-Woś, Zamek arcybiskupów gnieźnieńskich $w$ Uniejowie $w \mathrm{xv}$ wieku w'śietle źródet pisanych, „Biuletyn Uniejowski” 2015, t. 4, s. 45-62; P. Szkutnik, Pożyczka na budowę domu Franciszka i Jadwigi Gawrońskich w Uniejowie w I808 roku, „Biuletyn 
i archeologów ${ }^{3}$, chemików ${ }^{4}$, biologów i przyrodników ${ }^{5}$, inżynierów środowi-

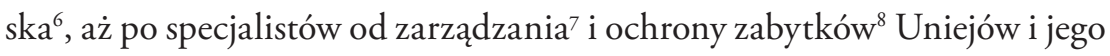
okolice dostarczają licznych tematów badawczych nie tylko naukowcom, ale

Uniejowski” 20I7, t. 6, s. I22-I29; Ł. Ćwikła, W sprawie agresji krzyżackiej na dobra kościelne w Łęczycy, Uniejowie i Sieradzu w I33I r. w'świetle akt procesu polsko-krzyżackiego w I339 r., „Łódzkie Studia Teologiczne” 2013, t. 22, s. 45-51; T. Wójcik (red.), Zapamiętane z Brückstädt. Wspomnienia wojenne mieszkańców ziemi uniejowskiej, Towarzystwo Przyjaciół Uniejowa, Uniejów 20I4; A. Jabłońska, Struktura kapituły uniejowskiej $w$ świetle "Liber beneficiorum” Jana Easkiego, „Acta Universitatis Lodziensis. Folia Historica" 200I, nr 72, s. 95-106.

3 M. Głosek, Badania na grodzisku w Smulsku i osadzie w Boleszynie, pow. Turek, „Sprawozdania Archeologiczne” 1969, t. 21, s. 197-202.

4 H. Bem, M. Olszewski, A. Kaczmarek, Concentration of selected natural radionuclides in the thermal groundwater of Uniejów, Poland, „Nukleonika” 2004, t. 49, nr I, s. I-5.

5 B. Chmielecki, L. Kucharski, Dendroflora cmentarzy $w$ gminie Uniejów - stan i problemy ochrony, „Biuletyn Uniejowski” 2015, t. 4, s. II3-I30; P. Chylarecki, A. Winiecki, K. Wypychowski, Awifauna legowa doliny Warty na odcinku Uniejów-Splawie, „Prace Zakładu Biologii i Ekologii Ptaków Uniwersytetu im. Adama Mickiewicza w Poznaniu" 1992, t. I, s. 7-55; P. Olejniczak, Wyniki inwentaryzacji gniazd bociana białego (ciconia ciconia) w gminach: Poddębice, Uniejów, Pęczniew i Zadzim w roku 1984, „Acta Universitatis Lodziensis. Folia Zoologica” 1992, nr I, s. 29-38; M. Cieślak, Ekologiczna optymalizacja przestrzennej struktury lasów na przykładzie gminy Uniejów, „Ochrona Środowiska i Zasobów Naturalnych” I993, nr 6, s. 59-76; M. Lisiewska, M. Rybak, Udziat macromycetes w zespołach leśnych parku w Uniejowie, „Badania Fizjograficzne nad Polską Zachodnią. Seria B” I990, t. 40 , s. 5-28.

6 M. Hämmerling, N. Walczak, P. Zawadzki, Wptyw zbiornika Jeziorsko na proces erozji podtużnej na dolnym odcinku Warty od zapory czołowej do miejscowości Uniejów, „Gospodarka Wodna” 2016, z. 9, s. 299-303; M. Michałowski, E. Saran, A. Wójcik, Geothermal energy in Uniejów-characteristics, „Inżynieria Mineralna” 2015, nr I6, s. I27-I32; A. Sapińska-Śliwa, P. Wojnarowski, A. Gonet, Analysis of Uniejów geothermal water reservoirs modeling in view of various aspects of geothermal water and heat management, [w:] Proceedings of World Geothermal Congress 20I0, 25-29 kwietnia 2010 r., Bali, Indonezja 2oıo; A. Sapińska-Śliwa, A. Lewkiewicz-Małysa, B. Winid, Wody termalne Uniejowa w świetle interpretacji wskaźników hydrochemicznych, „Wiertnictwo, Nafta, Gaz" 20II, t. 28, s. 359-369; P. Kubski, Ciepłownia geotermalna w Uniejowie na tle warunków hydrogeologicznych Polski, „Ciepłownictwo, Ogrzewnictwo, Wentylacja” 2006, nr 37, s. $3^{-5}$.

7 E. Gorczyczewska, K. Smętkiewicz, The use of territorial marketing in the development of the municipality-case study of the thermal SPA resort in Uniejow, „Intercathedra” 2013, nr 29 (4), s. 50-56.

8 K. Piotrowska-Nosek, The castle park in Uniejów: towards a restoration plan, „Monument: studies and materials of National Center for Historical Monument Studies and Documentation" 2005, t. I, s. 197-210. 
stanowią także interesujący obszar naukowy dla prac realizowanych przez doktorantów $^{9}$ i studentów ${ }^{10}$. Wpływa na to wiele czynników. Po pierwsze Uniejów i jego otoczenie mają długą historię osadnictwa, w ramach którego lokalizowały się liczne funkcje administracyjne i gdzie powstawała stosunkowo bogata dokumentacja, będąca cennym źródłem informacji historycznych $^{\text {II }}$. Poza tym wielowiekowe osadnictwo pozostawiało po sobie wiele reliktów o charakterze niepiśmiennym, zarówno w postaci materialnej ${ }^{\mathrm{I2}}$ (tj. związanej z rozplanowaniem, zabytkami), jak i niematerialnej ${ }^{13}$ (np. lokalne tradycje), które są przedmiotem zainteresowania geografów historycznych, historyków, archeologów i kulturoznawców. Od początku istnienia miasta oraz jego zaplecza zachodziły na jego terytorium rozmaite zjawiska, po dziś dzień badane przez historyków ${ }^{14}$. Po drugie, położenie ziemi uniejowskiej na skraju podziałów administracyjnych oraz fizycznogeograficznych (pogranicze Kotlin Kolskiej i Sieradzkiej oraz Wysoczyzn Łaskiej i Tureckiej z jednej strony oraz rejon styku dolin południkowej Warty i równoleżnikowo położonej warszawsko-berlińskiej z drugiej) stanowi interesujący obszar badań geograficznych ${ }^{\text {Is }}$. Dla przyrodników badających

9 K.A. Kurek, Geothermal resources and local development in Poland, (rozprawa doktorska), Wageningen University, Wageningen 202I.

Io R. Wiluś, Miasto i gmina Uniejów w pracach doktorskich, magisterskich i licencjackich opracowanych na Wydziale Nauk Geograficznych Uniwersytetu Eódzkiego, „Biuletyn Uniejowski” 20I2, t. I, s. 205-2I2; K.A. Kurek, Geothermal resources...

II P. Szkutnik, Regionalny poradnik genealogiczny - stan zachowania ksiag metrykalnych parafii rzymskokatolickich w gminie Uniejów, „Biuletyn Uniejowski” 20I2, t. I, s. $177^{-187}$.

I2 Por. M. Głosek, Badania na grodzisku...; T. Figlus, Rozwój układu ruralistycznego Spycimierza na tle dziejów osadnictwa w świetle badań geograficzno-historycznych $i$ archeologicznych, „Biuletyn Uniejowski”, 20I5, t. 4, s. 73-94.

I3 Por. P. Szkutnik, Początki tworzenia kompozycji z kwiatów na trasie procesji Bożego Ciała w Spycimierzu, „Archiwa, Biblioteki i Muzea Kościelne” 20I9, t. III, s. 33I-344; K. Smyk, Zmieniać rzeczy w znaki. Kod przedmiotowy w tradycji Bożego Ciała z kwietnymi dywanami w Spycimierzu, „Biuletyn Uniejowski” 2020, t. 9, s. 5-21; K. Smyk, Spycimierskie kwietne dywany na Boże Ciało - typologia i symbolika wzorów, „Biuletyn Uniejowski” 2019, t. 8, s. 35-65.

I4 Por. K.P. Woźniak, Próba uprzemystowienia Uniejowa w latach 20-30 XIX wieku, „Biuletyn Uniejowski” 2018, t. 7, s. I7-28; T. Wójcik, J. Boraś, Walki oddziatu wydzielonego pptk. Mariana Frydrycha z jednostkami 30 dywizji piechoty wehrmachtu o utrzymanie przeprawy mostowej w Uniejowie $w$ dn. 6-7 września I939 roku, „Biuletyn Uniejowski” 2020, t. 9, s. 23-57.

I5 E. Kobojek, Położenie fizycznogeograficzne miasta i gminy Uniejów, „Biuletyn Uniejowski” 20I2, t. I, s. 9-22. 
ziemię uniejowską ciekawym zagadnieniem jest różnorodność biologiczna, występująca na zróżnicowanych stanowiskach (m.in. w poszczególnych elementach doliny Warty, na obszarach poddanych antropopresji czy też terenach zieleni urządzonej) ${ }^{16}$. Kolejnymi, a w ostatnim czasie być może najważniejszymi atraktorami ogniskującymi na sobie uwagę naukowców na ziemi uniejowskiej są zidentyfikowane na przełomie lat 70. i 80. XX w. i wykorzystywane od przełomu wieków w coraz intensywniejszy sposób zasoby wód geotermalnych. Stały się one bezpośrednim lub pośrednim pretekstem do badań dla autorów reprezentujących wiele dziedzin naukowych. Począwszy od analiz samych zasobów, poprzez badania ich właściwości balneologicznych, po wpływ ich gospodarczego potencjału i wykorzystania w innych sferach rozwoju społeczno-gospodarczego ${ }^{17}$.

Opierając się na wymienionych przesłankach, podjęto decyzję o utworzeniu naukowego periodyku, który mógłby stać się płaszczyzną integrującą wspomniane wyżej badania, stanowiąc jednocześnie możliwie jak najbardziej kompletny zbiór materiałów badawczych i analiz dotyczących ziemi uniejowskiej. Mnogość tematów naukowych podejmowanych w periodyku oraz fakt, że jedynym elementem je integrującym jest obszar, którego one dotyczą, powoduje, że trudno jednoznacznie wskazać dominującą dyscyplinę naukową, w której „Biuletyn Uniejowski” powinien być ewaluowany. Niemniej jednak tego rodzaju czasopisma bywają niezwykle cenne i mają ogromne znaczenie dla lokalnej społeczności (co stanowi najważniejszy cel ich istnienia),

I6 Por. P. Chylarecki, A. Winiecki, K. Wypychowski, Awifauna legowa doliny...; L. Kucharski, A. Barcka, B. Chmielecki, Flora starorzeczy $w$ dolinie Warty - stan, zagrożenia oraz możliwości ochrony, „Biuletyn Uniejowski” 2013, t. 2, s. 23-38; L. Kucharski, B. Chmielecki, K. Figurska, Parki w Uniejowie i Turku ostojami rodzimej flory leśnej w rolniczym krajobrazie środkowej Polski, „Biuletyn Uniejowski” 20I9, t. 8, s. I8I-196.

I7 Por. E. Gorczyczewska, K. Smętkiewicz, The use of territorial marketing...; T. Latour, K. Smętkiewicz, Wtaściwości fizykochemiczne i chemiczne wód geotermalnych w Uniejowie ze szczególnym uwzględnieniem wody z odwiertu PIG/AGH-2, „Biuletyn Uniejowski” 20I2, t. I, s. 79-93; A. Sapińska-Śliwa, Udostępnianie wód termalnych w Uniejowie - rys historyczny, „Biuletyn Uniejowski” 20I2, t. I, s. 63-77; M. Kowalski, Pozarolnicza działalność gospodarcza w gminie Uniejów, „Biuletyn Uniejowski” 2015, t. 4, s. I43-I56; J. Krajewska, Atrakcyjność turystyczna gminy Uniejów w opinii turystów i kuracjuszy, „Biuletyn Uniejowski” 2016, t. 5, s. 193-207; P. Kurzyk, M. Kowalski, Popularność Uniejowa na tle małych miast regionu tódzkiego oraz konkurujących z nim uzdrowisk, „Biuletyn Uniejowski” 2019, t. 8, s. 77-97. 
odciskają również piętno na branżowych czasopismach naukowych głównego nurtu. Bieżący tom jest jubileuszowym, ıo. wydaniem rocznika. Wspomniany jubileusz to doskonała okazja do refleksji, podobnie jak te podejmowane $\mathrm{w}$ ramach jubileuszy innych bardziej sędziwych czasopism $^{\text {18 }}$, nad miejscem „Biuletynu Uniejowskiego” w obiegu naukowym. Jednym z jej elementów jest poniższy artykuł. Sam „Biuletyn Uniejowski” doczekał się już jednego jubileuszowego opracowania (z okazji pięciolecia), które zostało opracowane przez prof. Ewę Andrysiak i ukazało się w czasopiśmie naukowym „Rocznik Łódzki”.

Niniejsze opracowanie stanowi raport z całego okresu działalności czasopisma. Głównym celem jest wskazanie powiązań badań publikowanych na łamach „Biuletynu Uniejowskiego” z poszczególnymi dziedzinami i dyscyplinami naukowymi.

\section{Źródła danych i metody badań}

Praca naukowa to jedna z tych działalności, które trudno poddać jednoznacznej ocenie. Podobnie jest z jakością tekstów publikowanych w czasopismach. Problemy te wynikają przede wszystkim z różnic w zakresie metod badawczych, praktyk publikacyjnych oraz ogólnych trendów, wyznaczających kierunki badań w każdej z dziedzin, a nawet dyscyplin naukowych. Tym trudniejsze wydaje się być ukazanie znaczenia czasopisma w przypadku takich periodyków naukowych, jak „Biuletyn Uniejowski”, a więc wydawnictw o charakterze wielodziedzinowym i wielodyscyplinowym, którego główny zakres tematyczny ogranicza się do przestrzeni

I8 Por. T. Rusin, Analiza cytowań publikacji wydanych w czasopiśmie „Folia Turistica” w latach 1990-20I6, „Folia Turistica”, 20I9, nr 45, s. 45-74; J. Dobroszek, H. Waniak-Michalak, Artykut z okazji jubileuszu "Zeszytów Teoretycznych Rachunkowości” / On the anniversary of ZTR, „Zeszyty Teoretyczne Rachunkowości” 20I6, t. 90 (I46), s. II-40; J. Wiktor, Próba analizy bibliometrycznej publikacji 25. Zjazdu Katedr Marketingu, Handlu i Konsumpcji - doświadczenia przeszłości i wyzwania przyszłości, „Zeszyty Naukowe SGGW, Polityki Europejskie, Finanse i Marketing" 2016, nr I5 (64), s. 170-182; K. Bakuła, Z. Kurczyński, Assessment and bibliometric review of scientific achievements published in the Archives of Photogrammetry, Cartography and Remote Sensing, „Archiwum Fotogrametrii, Kartografii i Teledetekcji” 20I9, t. 3I, s. I45-166.

I9 E. Andrysiak, „Biuletyn Uniejowski” 20I2-20I6. Pięć lat w stużbie środowisku, „Rocznik Łódzki” 20I7, t. 67, s. $265^{-284}$. 
regionu uniejowskiego. Niemniej jednak warto, chociażby dla celów statystycznych, podejmować próby związane z samoewaluacją czasopisma, a idealnym pretekstem do tego wydaje się być okrągła, Io. rocznica funkcjonowania czasopisma na rynku wydawniczym. Ponieważ trudno sobie wyobrazić ocenę działalności czasopisma bez wykorzystania w tym celu wskaźników i mierników bibliometrycznych ${ }^{20}$, właśnie takie podejście zastosowano w badaniu. Jest to jednocześnie jedno z jego podstawowych ograniczeń, dlatego należy już tutaj wspomnieć o sposobie interpretacji wyników. Nie polega ona na ocenie poszczególnych artykułów ukazujących się w roczniku (te przecież przechodzą przez surowe procedury recenzenckie, zgodne z międzynarodowymi standardami wydawniczymi, czego potwierdzeniem jest indeksowanie czasopisma w międzynarodowych repozytoriach, takich jak CEEOL, oraz bazach bibliograficznych, m.in. ERIH PLUS), a stanowi jedynie próbę syntetycznego przedstawienia miejsca „Biuletynu Uniejowskiego” w rozlegle pojętej nauce.

Przyjęto, że głównym źródłem danych dotyczących cytowalności publikacji jest baza Google Scholar, a więc jedno z najpopularniejszych i najbardziej dostępnych źródeł informacji o cytowaniach ${ }^{21}$. Bywa ona wykorzystywana do analiz kondycji czasopism ${ }^{22}$. W celu zebrania danych nie posiłkowano się popularnym narzędziem Publish or Perish, a wszystkie rekordy pozyskiwano i katalogowano ręcznie, mając na względzie fakt, że baza Google Scholar wykorzystuje bibliografię załącznikową. Dzięki tego rodzaju „ręcznemu” przeszukiwaniu wyeliminowano typowe dla automatów błędy, polegające m.in. na zwielokrotnianiu cytowań, wskutek pobierania danych z różnych baz. Czasopisma, w których znalazło się powołanie na artykuł z „Biuletynu Uniejowskiego”, przyporządkowywano do dziedzin i dyscyplin ${ }^{23}$ według matrycy znajdującej się w załączniku na końcu artykułu (zał. I). Dodatkowo każde z nich było weryfikowane w systemie InCites Journal Citation Reports w celu

20 J. Bański, B. Solon, Ocena działalności naukowo-badawczej ośrodków geograficznych $w$ Polsce, „Przegląd Geograficzny” 2020, t. 92, z. I, s. 155-167.

2I A. Osiewalska, Mierniki oceny czasopism i naukowców, „Biuletyn EBIB” 2008, nr 8 (99).

22 P. Śleszyński, Pozycja polskich czasopism i serii geograficznych w swietle baz Google Scholar, „Przegląd Geograficzny” 2009, t. 8I, z. 4, s. 551-578.

23 Strukturalny podział nauki na dziedziny i dyscypliny prezentowany w całym artykule przyjęto zgodnie z Rozporządzeniem Ministra Nauki i Szkolnictwa Wyższego z dnia 20 września $2018 \mathrm{r}$. w sprawie dziedzin nauki i dyscyplin naukowych oraz dyscyplin artystycznych, Dz.U. 20I8, poz. I8I8. 
sprawdzenia ich współczynnika wpływu (impact factor, IF). Dane dotyczące współczynnika wpływu czasopism cytujących „Biuletyn Uniejowski” oraz znajdujących się na Web of Sciences (i jednocześnie na tzw. liście filadelfijskiej) pozyskiwano dla roku 2019.

W kontekście porównań dziedzinowych i dyscyplinowych artykuły publikowane w badanym czasopiśmie przypisywane były do sektorów nauki zgodnie $\mathrm{z}$ afiliacją autora lub w przypadku braku afiliacji naukowej - na podstawie analizy treści artykułu. W sytuacji gdy było wielu autorów z różnych dyscyplin, artykuł dzielono po równo na liczbę przypadających na niego dyscyplin (wyjątkiem od tego jest analiza cytowalności według dyscyplin, gdzie w przypadku interdyscyplinarnych zespołów autorskich artykuł dodawano do zestawień w obrębie każdej z reprezentowanych przez nich dyscyplin).

W ramach wybranych analiz wskazano także zestawienia cytowań czasopisma bez autocytowań. Wspomniane autocytowania były mierzone, a następnie przedstawione w wynikach w dwojaki sposób. Po pierwsze za swego rodzaju autocytowanie przyjmowano odniesienie się do artykułu w tym samym czasopiśmie, z którego cytowany tekst pochodził (cytowania wewnętrzne). Po drugie przeprowadzono kwerendę tekstów pod kątem autorskich autocytatów, której efektem były zestawienia wzmiankowań w artykułach napisanych przez innych niż artykuł cytowany autorów. Założono przy tym, że w przypadku artykułów wieloautorskich autocytowaniem jest każdy cytat w artykule, którego choć jeden autor jest ten sam.

W zakresie przedstawiającym wyniki parametryczne „Biuletynu Uniejowskiego" na tle innych czasopism posłużono się wskaźnikami Index Copernicus Value (ICV), pochodzącymi z ocen czasopism dokonywanych corocznie przez Index Copernicus International w ramach Journals Master List.

Obliczono także podstawowe wskaźniki bibliometryczne dla czasopisma. Po pierwsze policzono wskaźnik Hirscha (h-index), czyli liczbę prac o liczbie cytatów $\geq h^{24}$. W dalszej części poddano analizie rdzeń $h$, obliczając jego medianę (h-median). Wspomniane wskaźniki policzono zarówno dla czasopisma, jak i (ze względu na to, że „Biuletyn Uniejowski”

24 J.E. Hirsch, An index to quantify an individual's scientific research output, „Proceedings of the National academy of Sciences” 2005, t. IO2 (46), s. 16569-16572. 
jest periodykiem wielodziedzinowym) dla każdej z dziedzin i wybranych dyscyplin z osobna (tylko tych, które reprezentowane są przez co najmniej Io artykułów, przy czym w przypadku tekstów, których afiliacja autorów wskazywała na różne dziedziny, artykuł brał udział w procedurze obliczania h dla każdej z reprezentowanych dziedzin).

\section{Z historii „Biuletynu Uniejowskiego”}

Jak wspomniano we wstępie, bieżący tom „Biuletynu Uniejowskiego” jest Io. odsłoną tego rocznika wydawanego przez Uniwersytet Łódzki (przy zaangażowaniu redakcyjnym Instytutu Zagospodarowania Środowiska i Polityki Przestrzennej oraz Ośrodka Badawczego Europejskiej Polityki Przestrzennej i Rozwoju Lokalnego UŁ) we współpracy z Urzędem Miasta w Uniejowie. „Biuletyn Uniejowski” powstał z inicjatywy władz miasta oraz prof. Tadeusza Marszała. Pierwszym redaktorem naczelnym został prof. dr hab. T. Marszał (lata 20I2-20I3), kolejnym pani profesor UŁ, dr hab. Elżbieta Kobojek (20I4-2017). W $2018 \mathrm{r}$. poszerzono skład redakcji i w ramach jego reorganizacji funkcję redaktora naczelnego powierzono dr Marcie Borowskiej-Stefańskiej, zaś jej zastępcy - dr Edycie Masierek. Od początku istnienia rocznika członkami jego rady redakcyjnej były uznane autorytety naukowe z Polski i z zagranicy, a redakcja przyjęła międzynarodowe standardy wydawnicze, związane z formą udostępniania artykułów i dotyczące procedury recenzji.

„Biuletyn Uniejowski” aktualnie ukazuje się drukiem, ale jest również dostępny w ramach repozytoriów: Central and Eastern European Online Library (CEEOL), CEON Biblioteka Nauki oraz Repozytorium Uniwersytetu Łódzkiego. Do wymienionych wyżej repozytoriów doliczyć należy indeksowanie czasopisma w bazach: BazHum, CEJSH, EBSCO, ERIH PLUS, ProQuest oraz Index Copernicus International. Poza wcześniej wspomnianymi repozytoriami artykuły publikowane w „Biuletynie Uniejowskim” dostępne są w Internecie także na stronie czasopisma: http://www.biuletynuniejowski.geo.uni.lodz.pl/.

Do tej pory (wyłączając Io. tom) na łamach „Biuletynu Uniejowskiego” ukazało się II I cytowalnych artykułów, z czego 70 z nich zostało przynajmniej raz zacytowane. Struktura tematyczna prac potwierdza wielodycyplinowość czasopisma (ryc. I). Autorzy reprezentowali aż 6 dziedzin naukowych i I3 dyscyplin. Tym, co łączy wszystkie prace, jest ich ścisły związek ze zjawiskami i procesami dotyczącymi ziemi uniejowskiej. 


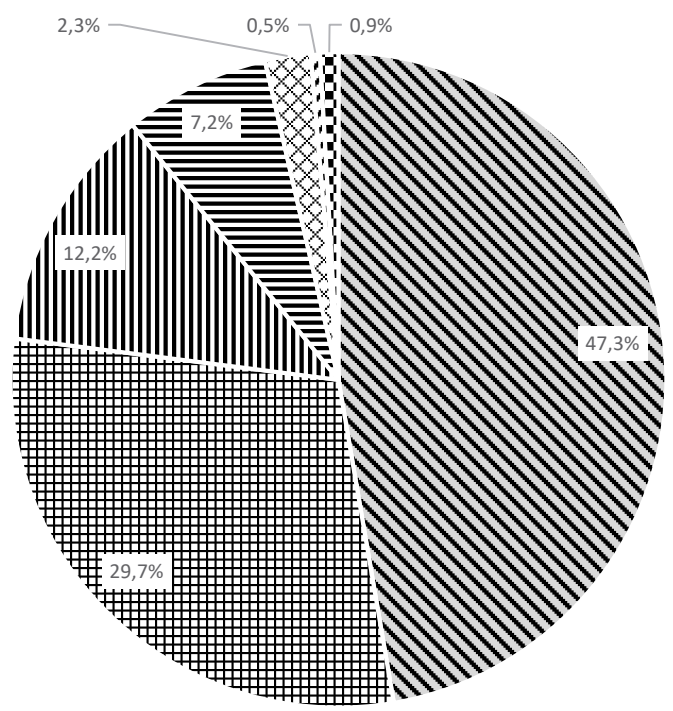

s nauki społeczne

II nauki ścisłe i przyrodnicze

$x$ nauki medyczne i nauki o zdrowiu

inne
\# nauki humanistyczne

= nauki inżynieryjno-techniczne

nauki rolnicze

Ryc. I. Struktura artykułów publikowanych w „Biuletynie Uniejowskim” wydanych w latach 20I2-2020 według dziedzin naukowych

Źródło: opracowanie własne

Wewnętrzna struktura reprezentowanych dziedzin naukowych jest zróżnicowana. Jedynie dwie dziedziny reprezentowane są przez jedną dyscyplinę (tab. I). Najliczniej reprezentowaną na łamach „Biuletynu Uniejowskiego" dziedziną naukową była geografia społeczno-ekonomiczna i gospodarka przestrzenna $(43,2 \%$ artykułów), kolejno historia $(23,4 \%)$ oraz nauki biologiczne $(6,3 \%)$.

Na łamach „Biuletynu Uniejowskiego” ukazały się do tej pory teksty 99 autorów (wyłączając bieżący, Io. tom). Do autorów najczęściej publikujących artykuły w analizowanym czasopiśmie zaliczyć należy: dra Błażeja Chmieleckiego (9 artykułów), prof. Leszka Kucharskiego (7), dra Piotra Szkutnika, dra Tomasza Figlusa (obaj po 6) oraz dr Martę Borowską-Stefańską (5).

Redakcja czasopisma poddaje się corocznie ocenie - pierwszej, dokonywanej indywidualnie przez każdego z czytelników, i drugiej - dokonywanej 
przez międzynarodową bazę indeksacyjną czasopism naukowych ICI Journals Master List. Wynikiem drugiej ze wspomnianych ocen jest wskaźnik ICV (Index Copernicus Value), który stanowi miarę mocy czasopisma naukowego ${ }^{25}$. W rezultacie prowadzonej przez zewnętrznego audytora ewaluacji „Biuletyn Uniejowski” otrzymał ocenę 66,I5 (stan z 2019 r.), a wartość ta prezentuje wyraźny trend wzrostowy (ryc. 2).

Tabela I. Wewnętrzna struktura dziedzin naukowych znajdujących reprezentację w „Biuletynie Uniejowskim” w latach 2012-2020

\begin{tabular}{|c|c|c|}
\hline Dziedzina & Dyscyplina & $\begin{array}{l}\text { Udział autorów z danej } \\
\text { dyscypliny w ogóle } \\
\text { artykułów z dziedziny }\end{array}$ \\
\hline \multirow{4}{*}{ Nauki społeczne } & $\begin{array}{c}\text { geografia społeczno-ekonomiczna } \\
\text { i gospodarka przestrzenna }\end{array}$ & $9 \mathrm{I}, 4 \%$ \\
\hline & nauki o zarządzaniu i jakości & $5,7 \%$ \\
\hline & $\begin{array}{l}\text { nauki o komunikacji } \\
\text { społecznej i mediach }\end{array}$ & $I, 9 \%$ \\
\hline & nauki socjologiczne & $\mathrm{I}, \mathrm{O} \%$ \\
\hline \multirow{3}{*}{$\begin{array}{c}\text { Nauki } \\
\text { humanistyczne }\end{array}$} & historia & $78,8 \%$ \\
\hline & nauki o kulturze i religii & I $8,2 \%$ \\
\hline & językoznawstwo & $3,0 \%$ \\
\hline \multirow{2}{*}{$\begin{array}{l}\text { Nauki ścisłe } \\
\text { i przyrodnicze }\end{array}$} & nauki biologiczne & $51,9 \%$ \\
\hline & nauki o Ziemi i środowisku & $48, \mathrm{I} \%$ \\
\hline \multirow{2}{*}{$\begin{array}{l}\text { Nauki } \\
\text { inżynieryjno- } \\
\text {-techniczne }\end{array}$} & architektura i urbanistyka & $50,0 \%$ \\
\hline & $\begin{array}{l}\text { inżynieria środowiska, } \\
\text { górnictwo i energetyka }\end{array}$ & $50,0 \%$ \\
\hline $\begin{array}{c}\text { Nauki medyczne } \\
\text { i nauki } \\
\text { o zdrowiu }\end{array}$ & nauki o zdrowiu & $100 \%$ \\
\hline Nauki rolnicze & zootechnika i rybactwo & $\mathrm{IOO} \%$ \\
\hline
\end{tabular}

Źródło: opracowanie własne

25 https://indexcopernicus.com/index.php/pl/parametryzacja-menu/journals-master-list [dostęp: 22.05.2021]. 


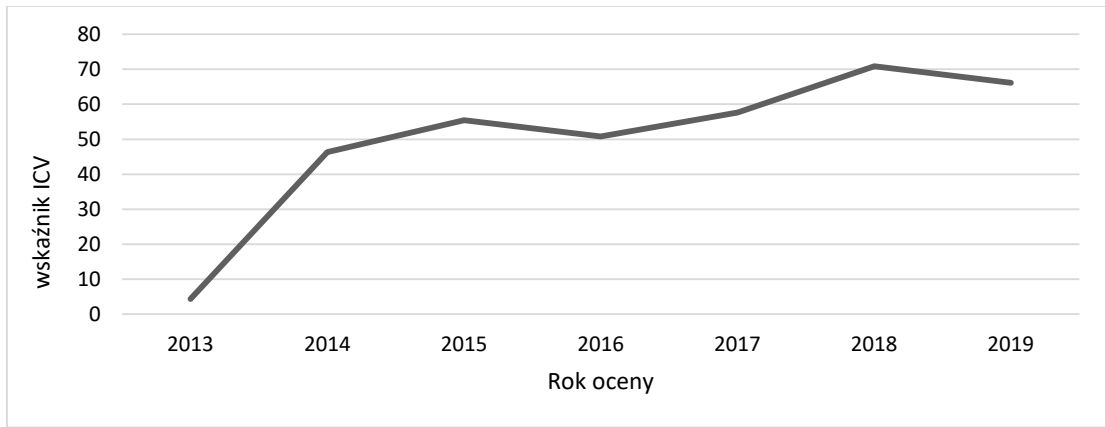

Ryc. 2. Zmiana wskaźnika ICV dla czasopisma „Biuletyn Uniejowski” w latach $2013^{*}$-2019 (*do 2013 r. obowiązywała inna metodyka oceny czasopism) Źródło: opracowanie własne na podstawie danych Index Copernicus International

W latach 2015-2018 „Biuletyn Uniejowski” znajdował się na listach Ministerstwa Nauki i Szkolnictwa Wyższego (MNisw) - lista B, z przyznaną liczbą 4 punktów za publikację. Po reformie związanej między innymi ze sposobami ewaluacji czasopism „Biuletyn Uniejowski”, podobnie jak wiele innych czasopism naukowych, nie został uwzględniony na listach MNisw i z tego powodu za publikację na jego łamach przyznawanych jest 5 punktów.

\section{Wyniki}

Ogółem artykuły publikowane na łamach „Biuletynu Uniejowskiego” cytowane były 254 razy, z czego 106 cytowań ma swoje źródło w wydawnictwach innych niż poddane analizie czasopismo, zaś 193 cytowania artykułów wydanych w „Biuletynie Uniejowskim” pochodzi z tekstów napisanych przez innych autorów niż cytowany tekst źródłowy. Dominująca dziedzina naukowa, w której daje się zaobserwować wpływ czasopisma, to dziedzina nauk społecznych (ryc. 3). Przyjmując, że głównym profilem „Biuletynu Uniejowskiego” jest właśnie ta dziedzina, to udział cytowań w niej wyniósłby $79 \%$.

Wskaźnik Hirscha (obliczony dla całego okresu wydawania czasopisma 9 lat) wyniósł 9 (w przypadku wykluczenia cytowań wewnętrznych $\mathrm{h}=5$, zaś wyłączając autocytowania $\mathrm{h}=7$ ). Wskaźnik h-median wyniósł odpowiednio: 9 w przypadku cytowań rozpatrywanych całościowo, 7 bez cytowań wewnętrznych i $9 \mathrm{z}$ wyłączeniem autocytowań. Wspomniane wskaźniki obliczane dla poszczególnych dziedzin i wybranych dyscyplin zaprezentowano w tab. 2. 


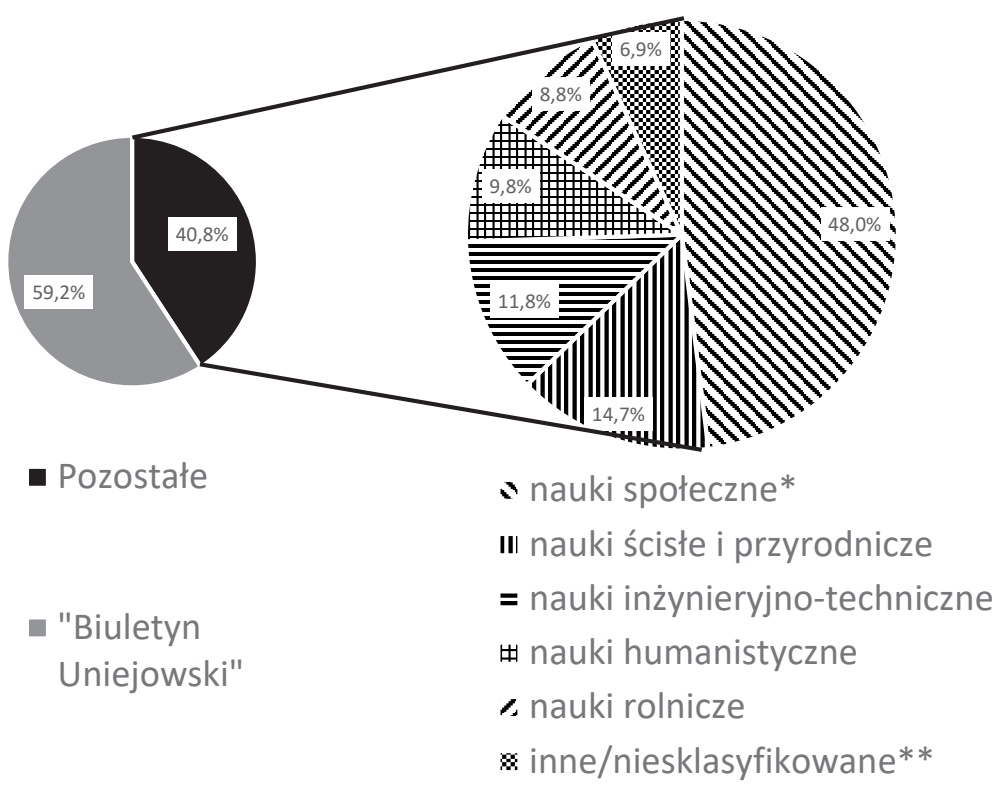

*bez "Biuletynu Uniejowskiego"

** materiały i publikacje konferencyjne (wielodziedzinowe), monografie, rozdziały w monografiach i doktoraty

Ryc. 3. Struktura cytowań artykułów z „Biuletynu Uniejowskiego” według dziedzin naukowych (stan z dnia 30 marca 202I r.)

Źródło: opracowanie własne

Cytowalność artykułów wydanych w „Biuletynie Uniejowskim” wyraźnie wzrasta odpowiednio do czasu, w jakim przywołane treści funkcjonują w otwartym dostępie (tab. 3). Wspomniana tendencja jest naturalna, gdyż wraz z wydłużaniem się czasu od publikacji zwiększa się prawdopodobieństwo jego zacytowania. Należy przy tym także zwrócić uwagę na fakt, że publikacja artykułów w analizowanym roczniku następuje z reguły na przełomie listopada i grudnia, a więc stosunkowo późno, co może być przyczyną niższej cytowalności artykułów z ostatnich dwóch lat (w chwili kiedy pisany jest niniejszy tekst, od publikacji 9. tomu minęły zaledwie 4 miesiące).

Dotychczas dwa artykuły, które ukazały się na łamach „Biuletynu Uniejowskiego”, zostały zacytowane w pracach opublikowanych w czasopismach legitymujących się współczynnikiem impact factor i notowanych na prestiżowej Web of Science (popularnie nazywanej listą filadelfijską). Obydwa cytowane tam artykuły są z zakresu geografii społeczno-ekonomicznej i gospodarki przestrzennej. Pierwszy z nich cytowany jest w dwóch opracowaniach o wskaźniku IF 20I9 kolejno: 2,239 („ISPRS International Journal of Geo-Information”) 
i o,957 („Geografie-Sbornik CGs”), w czasopismach z zakresu geografii społeczno-ekonomicznej i gospodarki przestrzennej. Drugi cytowany jest raz w jednym z czasopism z zakresu inżynierii środowiska, górnictwa i energetyki („Energy Reports”) o współczynniku IF wynoszącym 3,595.

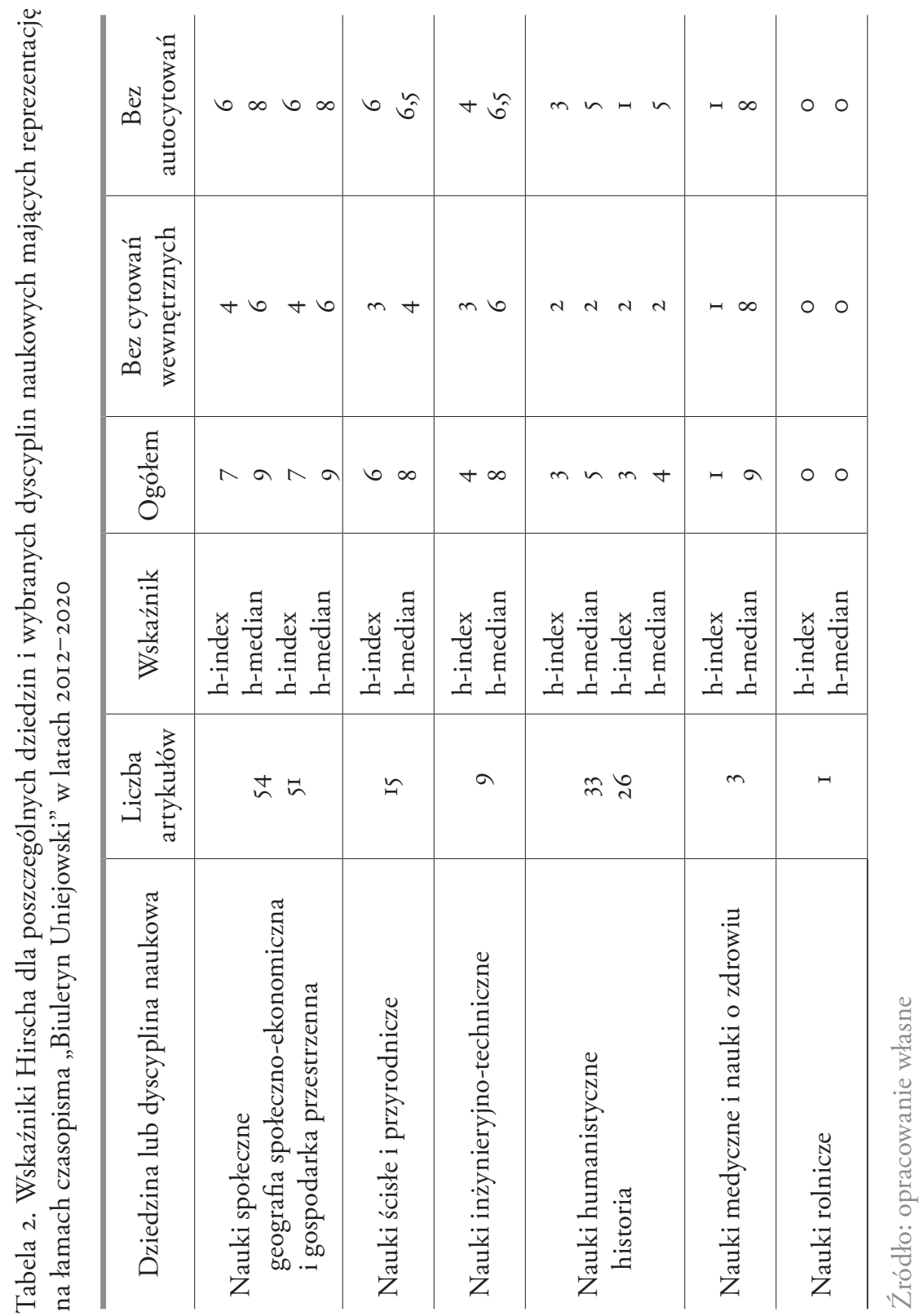


Tabela 3. Wybrane wskaźniki bibliometryczne dla poszczególnych tomów „Biuletynu Uniejowskiego" za okres 2012-202I

\begin{tabular}{|c|c|c|c|c|c|c|c|c|c|}
\hline Tom & I & 2 & 3 & 4 & 5 & 6 & 7 & 8 & 9 \\
\hline Liczba cytowanych artykułów & $\mathrm{I} 3$ & IO & II & I5 & $\mathrm{I} 4$ & I5 & $\mathrm{I} 2$ & $\mathrm{I} 2$ & 9 \\
\hline $\begin{array}{c}\text { Liczba cytowań } \\
\text { w czasopismach o obliczonym } \\
\text { współczynniku wpływu (IF) }\end{array}$ & O & O & 2 & I & 0 & 0 & 0 & 0 & O \\
\hline $\begin{array}{l}\text { Ogółem cytowań } \\
\text { na pracę }\end{array}$ & 6,4 & 4 & 3,5 & 3,3 & $\mathrm{I}, \mathrm{I}$ & 0,6 & $\mathrm{I}, \mathrm{I}$ & 0,4 & o \\
\hline $\begin{array}{l}\text { Cytowań na pracę } \\
\text { bez cytatów } \\
\text { wewnętrznych }\end{array}$ & 2,4 & $\mathrm{I}, 8$ & $2, \mathrm{I}$ & $\mathrm{I}, 6$ & O,I & 0,3 & 0,3 & 0 & O \\
\hline $\begin{array}{l}\text { Cytowań na pracę } \\
\text { bez autocytowań }\end{array}$ & 5,7 & $3, \mathrm{I}$ & 2,5 & 2,2 & 0,6 & 0,5 & 0,7 & 0,2 & O \\
\hline Ogółem h-index & 7 & 4 & 4 & 4 & 2 & 2 & 2 & I & $\mathrm{O}$ \\
\hline Ogółem h-median & 9 & 7 & 8 & 8 & 3 & 3 & 3 & I & 0 \\
\hline $\begin{array}{l}\text { h-index bez cytowań } \\
\text { wewnętrznych } \\
\text { (za cały okres) }\end{array}$ & 3 & 3 & 3 & 3 & I & I & I & 0 & O \\
\hline $\begin{array}{c}\text { h-median bez cytowań } \\
\text { wewnętrznych }\end{array}$ & 6 & 3 & 7 & 4 & I & I & I & 0 & O \\
\hline
\end{tabular}

\section{Źródło: opracowanie własne}

Artykuły z dziedziny nauk społecznych są najczęściej cytowanymi treściami publikowanymi w „Biuletynie Uniejowskim” (47\% ogółu cytowań i 40\% cytowań zewnętrznych dotyczy tych artykułów), natomiast 62\% cytowań artykułów z tej dziedziny to odniesienia wewnętrzne. Rozkład cytowań zewnętrznych wskazuje na dominację cytujących teksty opublikowane w czasopismach z dyscypliny geografia społeczno-ekonomiczna i gospodarka przestrzenna (67\%) i zdecydowanie rzadziej w dyscyplinach: inżynieria 
środowiska, górnictwo i energetyka (6\%), inżynieria lądowa i transport (6\%), inżynieria mechaniczna (4\%), historia (4\%). 22\% ogółu cytowań (25\% cytowań zewnętrznych) stanowią cytowania tekstów afiliowanych przez przedstawicieli nauk ścisłych i przyrodniczych, 49\% cytatów z tych artykułów to cytowania wewnętrzne, z kolei wśród cytowań zewnętrznych dominują te pochodzące z dyscyplin: nauki o Ziemi i środowisku (3I\%), nauki leśne (I6\%), geografia społeczno-ekonomiczna i gospodarka przestrzenna (I3\%) oraz nauki biologiczne (I3\%). Poza nimi zauważalne są cytowania w czasopismach z dyscyplin: rolnictwo i ogrodnictwo (9\%) i inżynieria mechaniczna (6\%). Kolejną dziedziną pod względem liczby cytowań są nauki humanistyczne (I3\% ogółu cytowań i 7\% cytowań zewnętrznych). Publikacje autorów z afiliacją wskazującą na pracę badawczą w zakresie danej dziedziny cytowano na ogół w „Biuletynie Uniejowskim” (76\% cytowań), zaś w odniesieniu do cytowań zewnętrznych odnaleźć można je wśród takich dyscyplin, jak: historia (4 cytaty), geografia (2), językoznawstwo (2) i nauki prawne (I cytat). Reprezentanci piszący dla „Biuletynu Uniejowskiego” i afiliujący się do jednostek z zakresu dziedziny nauk inżynieryjno-technicznych cytowani byli w tej samej liczbie co w przypadku dziedziny nauki humanistyczne. $29 \%$ odniesień do tych tekstów to cytaty wewnętrzne, zaś udziały w zewnętrznych powołaniach się na wspomniane teksty prezentuja się następująco: 4I\% z nich to cytowania z czasopism z zakresu geografii społeczno-ekonomicznej i gospodarki przestrzennej, I5 \% z nich pochodzi z czasopism z zakresu nauk o Ziemi i środowisku, zaś pozostałe dzielą się pomiędzy: historię oraz architekturę i urbanistykę (po 2 cytaty), a także po I cytacie w czasopismach z zakresu ekonomii i finansów, nauk biologicznych, inżynierii mechanicznej, nauk leśnych i archeologii. Nauki medyczne i nauki o zdrowiu (a właściwie jedyna reprezentowana przez nie dyscyplina nauki o zdrowiu) cytowana była łącznie Io razy, z czego raz na łamach „Biuletynu Uniejowskiego”. Pozostałe cytowania pochodzą z czasopism z zakresu geografii społeczno-ekonomicznej i gospodarki przestrzennej (4 cytaty), inżynierii środowiska, górnictwa i energetyki (2 cytowania) oraz inżynierii mechanicznej, historii i innych niesklasyfikowanych (po I cytacie). Wyżej opisane ujęcie dziedzinowo-dyscyplinowe zostało szczegółowiej ukazane w formie graficznej w podejściu dyscyplinowo-dyscyplinowym (ryc. 4).

Stosunkowo duża liczba cytowań wewnętrznych nie powinna dziwić. To w znacznej mierze pochodna profilu czasopisma, w którym wszystkie tematy ogniskują się wokół ziemi uniejowskiej. Jako że jest to jedyne 


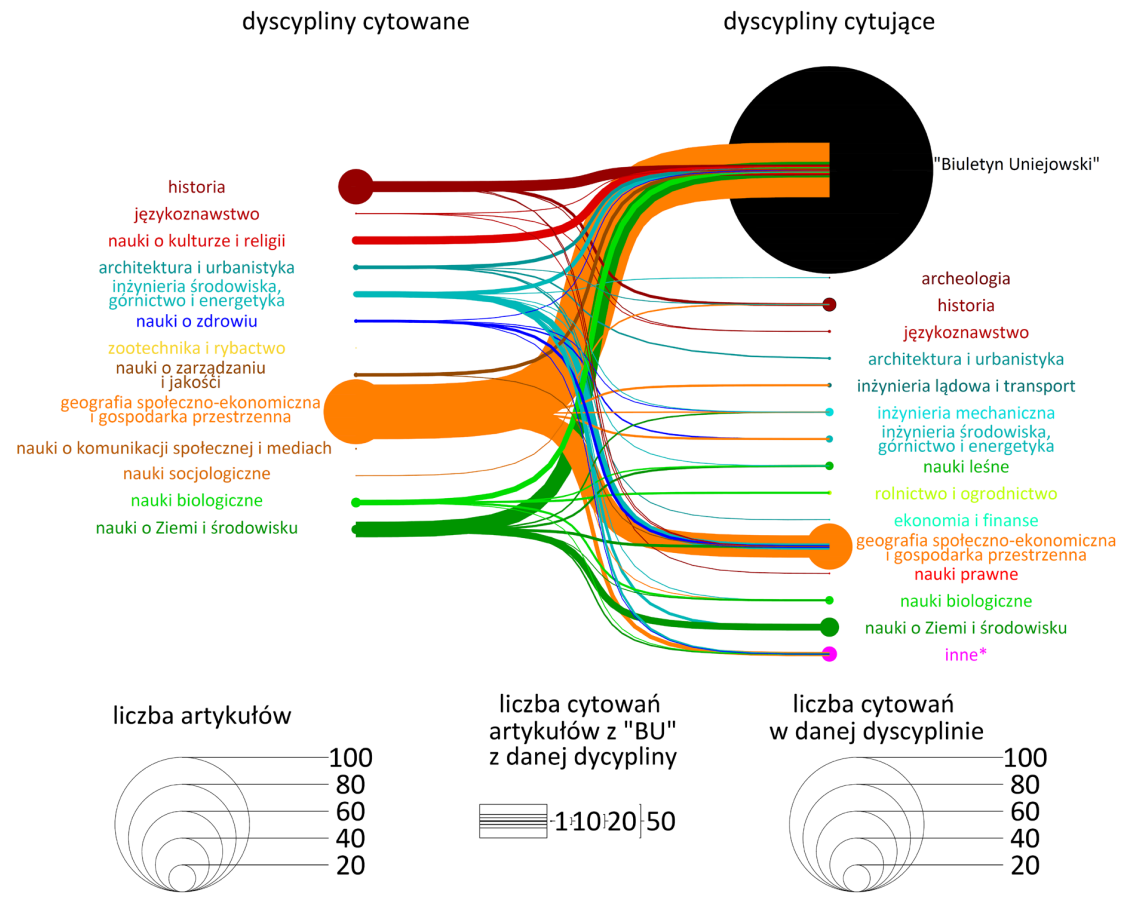

* materiały i publikacje konferencyjne (wielodziedzinowe), monografie i rozdziały w monografiach i doktoraty

Ryc. 4. Cytowania według dyscyplin naukowych artykułów opublikowanych w „Biuletynie Uniejowskim” oraz ich struktura podziału na cytujące je artykuły według dyscypliny czasopisma, w którym się ukazały (stan z dnia 30 marca 202 I r.) Źródło: opracowanie własne

czasopismo naukowe dotyczące lokalnych problemów tego rejonu, nie ma innego, bardziej odpowiedniego miejsca, w którym badania publikowane w „Biuletynie Uniejowskim” mogłyby być często cytowane. Z kolei autorzy piszący dla „Biuletynu Uniejowskiego” przeprowadzają w sposób naturalny kwerendę dotychczasowych tomów, traktując ten periodyk jak jedno z najlepszych źródeł naukowych informacji o tym regionie i stąd często cytują inne teksty wcześniej opublikowane w „Biuletynie”.

Podejmując próbę zestawienia oceny czasopisma z oceną innych czasopism naukowych, posłużono się wskaźnikiem ICV. Porównanie jego wyniku dla „Biuletynu Uniejowskiego” (ICV = 66, I5; stan z 2019 r.) z innymi polskimi czasopismami, podobnie jak on indeksowanymi w kategoriach 
geografia (średnia 86, I7; przy $\sigma=\mathrm{I9}, 42)^{26}$ lub historia (średnia 76, I I przy $\sigma=19,74)^{27}$, a więc najliczniej reprezentowanych poprzez artykuły ukazujące się w periodyku, należy stwierdzić, że jak na czasopismo o wybitnie lokalnym charakterze, szczególnie w tej drugiej kategorii, „Biuletyn Uniejowski” oceniany jest dość dobrze (znajduje się powyżej 25. percentyla wyznaczanego przez próg 64,07).

Do najczęściej cytowanych prac, które ukazały się na łamach „Biuletynu Uniejowskiego”, należą prace z zakresu rozlegle rozumianej geografii, a także artykuły dotyczące właściwości wód geotermalnych i sposobów ich udostępniania (tab. 4).

\section{Podsumowanie}

Niemal połowa artykułów publikowanych w „Biuletynie Uniejowskim” to teksty mieszczące się w dziedzinie nauk społecznych, których większość związana jest z geografią społeczno-ekonomiczną i gospodarką przestrzenną. W rezultacie to właśnie w czasopismach z tej dyscypliny odnaleźć można najwięcej cytowań. Niemniej jednak czasopismo wciąż utrzymuje wielodyscyplinowy charakter, czego dowodzi brak ponad 50\% udziałów jednej dyscypliny, zarówno we wcześniej wspomnianym zakresie związanym z liczbą artykułów, jak i w przypadku braku takiej dominacji w obrębie cytowań (największą wartość - 45\% - stanowią cytowania w ramach dziedziny nauk społecznych, zaś pozostałe cytowania reprezentowane są $\mathrm{w}$ dziedzinach: nauki ścisłe i przyrodnicze (I6\%), nauki inżynieryjno-techniczne (I3\%), nauki humanistyczne (IO\%) i nauki rolnicze (7\%), pozostała część cytowań pochodzi z niesklasyfikowanych materiałów i publikacji konferencyjnych, monografii oraz ich rozdziałów, a także z doktoratów.

26 Do najbliższych sześciu „sąsiadów” w rankingu w tej kategorii należą: „Biuletyn Szadkowski” (ICV = 71,25), „Acta Scientiarum Polonorum. Administratio Locorum” (70,92), „Turystyka Kulturowa” (66,69), „Space - Society - Economy” (56,57), „Transport Miejski i Regionalny” (56,03) i „Studia Obszarów Wiejskich” (51,28).

27 Do najbliższych sześciu „sąsiadów” w rankingu w tej kategorii należą: „Roczniki Naukowe Wyższej Szkoły Wychowania Fizycznego i Turystyki w Białymstoku” (ICV = 66,65), „Annales Universitatis Paedagogicae Cracoviensis. Studia Historicolitteraria” (66,58), „Rocznik Przemyski Historia” (66,55), „Studia z dziejów średniowiecza” (65,69), „Wadoviana. Przegląd historyczno-kulturalny” (65,6I) i „Komunikaty Mazursko-Warmińskie” (65,36). 
Tabela 4. Artykuły o najwyższej liczbie cytowań* spośród wszystkich opublikowanych w „Biuletynie Uniejowskim” - stan z marca 202 I r.

\begin{tabular}{|c|c|c|c|c|}
\hline Autor/Autorzy & Tytuł & 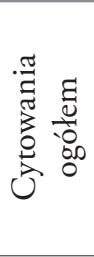 & 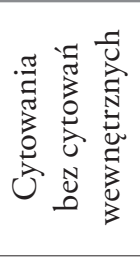 & 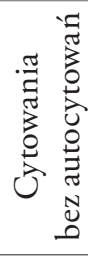 \\
\hline E. Kobojek & $\begin{array}{l}\text { Położenie fizycznogeograficzne } \\
\text { gminy i miasta Uniejów }\end{array}$ & I2 & I & I2 \\
\hline S. Wiśniewski & $\begin{array}{c}\text { Dostępność transportowa } \\
\text { Uniejowa - ujęcie regionalne }\end{array}$ & II & 7 & 6 \\
\hline A. Wojnarowska & $\begin{array}{c}\text { Przestrzeń publiczna } \\
\text { Uniejowa }\end{array}$ & II & 4 & 8 \\
\hline $\begin{array}{l}\text { T. Latour, } \\
\text { K. Smętkiewicz }\end{array}$ & $\begin{array}{l}\text { Właściwości fizykochemiczne } \\
\text { i chemiczne wód geotermalnych } \\
\text { w Uniejowie ze szczególnym } \\
\text { uwzględnieniem wody } \\
\text { odwiertu PIG/AGH-2 }\end{array}$ & 9 & 8 & 8 \\
\hline $\begin{array}{l}\text { M Gorączko, } \\
\text { B. Pawłowski }\end{array}$ & $\begin{array}{l}\text { Przebieg zjawisk lodowych na } \\
\text { Warcie w rejonie Uniejowa }\end{array}$ & 7 & 7 & 6 \\
\hline $\begin{array}{l}\text { J. Petera- } \\
- \text { Zganiacz }\end{array}$ & $\begin{array}{c}\text { Historia rozwoju doliny } \\
\text { Warty w basenie uniejowskim }\end{array}$ & IO & 3 & 9 \\
\hline $\begin{array}{l}\text { A. Sapińska- } \\
\text {-Śliwa }\end{array}$ & $\begin{array}{l}\text { Udostępnianie wód } \\
\text { termalnych w Uniejowie - } \\
\text { rys historyczny }\end{array}$ & 9 & 6 & 9 \\
\hline M. Lamprecht & $\begin{array}{c}\text { Kilka uwag o rozwoju } \\
\text { Uniejowa w świetle nowych } \\
\text { funkcji miasta }\end{array}$ & 9 & 2 & 9 \\
\hline
\end{tabular}

*W tabeli uwzględniono jedynie artykuły o 3 najwyższych miarach w zakresie liczby cytowań wg poszczególnych kryteriów (wynik kryterium, na podstawie którego zaprezentowano artykuł w zestawieniu, został wytłuszczony i podkreślony)

Źródło: opracowanie własne 
Obecność „Biuletynu Uniejowskiego” jest zauważalna nie tylko w lokalnym środowisku. Prace w nim publikowane trafiają także do obiegu naukowego, przyczyniając się do poszerzenia horyzontów poznawczych. Wpływ analizowanego czasopisma na naukę nie jest duży, nie jest nawet średni - jednak pomimo ograniczonej skali dotyczącej zasięgu badań wykorzystywane w nich metody lub zaprezentowane w nich wyniki bywaja cennym źródłem dla naukowców piszących w specjalistycznych czasopismach. Zważywszy na fakt lokalnej skali badań, rola czasopisma nie wydaje się być mało znacząca na tle innych mu podobnych wydawnictw. Niemniej jednak, aby móc jednoznacznie ocenić „Biuletyn Uniejowski”, należałoby przeprowadzić bardziej kompleksowe badania w całej grupie czasopism naukowych o podobnym do niego profilu.

\section{Bibliografia}

Andrysiak E., „Biuletyn Uniejowski” 20I2-20I6. Pięć latw stużbie środowisku, „Rocznik Łódzki” 20I7, t. 67, s. 265-284.

Bakuła K., Kurczyński Z., Assessment and bibliometric review of scientific achievementspublished in the Archives of Photogrammetry, Cartography and Remote Sensing, „Archiwum Fotogrametrii, Kartografii i Teledetekcji” 20I9, t. 3I, s. I45-I66. https://doi.org/IO.2478/apcrs-20I9-OoIO

Bański J., Solon B., Ocena dziatalności naukowo-badawczej ośrodków geograficznych w Polsce, „Przegląd Geograficzny” 2020, t. 92, z. I, s. I55-167. https://doi.org/I0.7163/PrzG.2020.I.9

Bem H., Olszewski M., Kaczmarek A., Concentration of selected natural radionuclides in the thermal groundwater of Uniejów, Poland, „Nukleonika” 2004, t. 49, nr I, s. I-5.

Borowska-Stefańska M., Ocena ryzyka powodziowego jako element wdrażania Dyrektywy Powodziowej - przykład Uniejowa, „Problemy Rozwoju Miast” 20I4, nr 3, s. 5-II.

Chmielecki B., Kucharski L., Dendroflora cmentarzy w gminie Uniejów stan i problemy ochrony, „Biuletyn Uniejowski” 20I5, t. 4, s. II3-I3O.

Chylarecki P., Winiecki A., Wypychowski K., Awifauna legowa doliny Warty na odcinku Uniejów-Splawie, „Prace Zakładu Biologii i Ekologii Ptaków Uniwersytetu im. Adama Mickiewicza w Poznaniu” I992, t. I, s. $7^{-55}$. 
Cieślak M., Ekologiczna optymalizacja przestrzennej struktury lasów na przykładzie gminy Uniejów, „Ochrona Środowiska i Zasobów Naturalnych” 1993, nr 6, s. 59-76.

Ćwikła Ł., W sprawie agresji krzyżackiej na dobra kościelne w Łęczycy, Uniejowie i Sieradzu w I33 I r. w świetle akt procesu polsko-krzyżackiego w I339 r., „Łódzkie Studia Teologiczne” 2013, t. 22, s. 45-51.

Dobroszek J., Waniak-Michalak H., Artykuł z okazji jubileuszu „Zeszytów Teoretycznych Rachunkowości”/ On the anniversary of ZTR, „Zeszyty Teoretyczne Rachunkowości” 2016, t. 90 (I46), s. I I-40.

Dzieduszyńska D., Kittel P., Basen uniejowski - historia i stan badań paleogeograficznych basenu uniejowskiego w badaniach Uniwersytetu Eódzkiego, „Biuletyn Uniejowski” 2012, t. I, 190-203.

Figlus T., Rozwój układu ruralistycznego Spycimierza na tle dziejów osadnictwa w świetle badan geograficzno-historycznych i archeologicznych, „Biuletyn Uniejowski”, 2015, t. 4, s. 73-94.

Frydrych M., Wybrzeże klifowe zbiornika Jeziorsko i jego znaczenie $w$ badaniach geomorfologicznych i paleogeograficznych, „Acta Universitatis Lodziensis. Folia Geographica Physica" 2013, nr I2, s. II7-I25.

Głosek M., Badania na grodzisku w Smulsku i osadzie w Boleszynie, pow. Turek, „Sprawozdania Archeologiczne” 1969, t. 21, s. 197-202.

Gorczyczewska E., Smętkiewicz K., Budowa i promocja marki miejsca na przyktadzie uzdrowiska termalnego Uniejów, „Studia Ekonomiczne” 2013, nr I44, s. 395-408.

Gorczyczewska E., Smętkiewicz K., The use of territorial marketing in the development of the municipality-case study of the thermal SPA resort in Uniejow, „Intercathedra” 2013, nr 29 (4), s. 50-56.

Hämmerling M., Walczak N., Zawadzki P., Wpływ zbiornika Jeziorsko na proces erozji podtużnej na dolnym odcinku Warty od zapory czotowej do miejscowości Uniejów, „Gospodarka Wodna” 2016, z. 9, s. 299-303.

Hirsch J.E., An index to quantify an individual's scientific research output, "Proceedings of the National academy of Sciences” 2005, t. I02 (46), s. I6569-I6572. https://doi.org/I0.1073/pnas.0507655102

https://indexcopernicus.com/index.php/pl/parametryzacja-menu/journals-master-list [dostęp: 22.05.202I].

Jabłońska A., Struktura kapituly uniejowskiej w świetle "Liber beneficiorum” Jana Easkiego, „Acta Universitatis Lodziensis. Folia Historica” 200I, nr 72, s. 95-106. 
Kaczmarek I., Ziemia Uniejowska w księgozbiorze Biblioteki Geograficznej Uniwersytetu Łódzkiego, „Biuletyn Uniejowski” 2018, t. 7, s. I8I-199. https://doi.org/I0.18778/2299-8403.07.12

Kaczmarek S., Kaczmarek J., Powiazania przestrzenne, społeczne i ekonomiczne w regionie tódzkim. Rejon Poddębice-Turek, „Acta Universitatis Lodziensis. Folia Geographica Socio-Oeconomica” 1999, nr I, s. I83-197.

Kobojek E., Położenie fizycznogeograficzne miasta i gminy Uniejów, „Biuletyn Uniejowski” 2012, t. I, s. 9-22.

Kobojek E., Problem przestrzennego rozwoju miast $w$ dolinach rzecznych na przykładzie Łowicza i Uniejowa, [w:] B. Więzik (red.), Prawne, administracyjne $i$ środowiskowe uwarunkowania zagospodarowania dolin rzecznych, Wyższa Szkoła Administracji, Bielsko-Biała 2013, s. 15-26.

Koter M., Środowisko geograficzne obszaru Uniejowa jako podtoże rozwoju osadnictwa i gospodarki, [w:] J. Szymczak (red.), Uniejów. Dzieje miasta, Towarzystwo Przyjaciół Uniejowa, Łódź-Uniejów 1995, s. 19-47.

Kowalski M., Pozarolnicza działalność gospodarcza w gminie Uniejów, „Biuletyn Uniejowski" 2015, t. 4, s. I43-156.

Krajewska J., Atrakcyjność turystyczna gminy Uniejów w opinii turystów i kuracjuszy, „Biuletyn Uniejowski” 2016, t. 5, s. 193-207. https://doi. org/I0.18778/2299-8403.05.13

Kubski P., Cieplownia geotermalna w Uniejowie na tle warunków hydrogeologicznych Polski, „Ciepłownictwo, Ogrzewnictwo, Wentylacja” 2006, nr 37, s. $3^{-5}$.

Kucharski L., Barcka A., Chmielecki B., Flora starorzeczy $w$ dolinie Warty - stan, zagrożenia oraz możliwości ochrony, „Biuletyn Uniejowski” 20I3, t. 2, s. $23^{-} 38$.

Kucharski L., Chmielecki B., Figurska K., Parki w Uniejowie i Turku ostojami rodzimej flory leśnej w rolniczym krajobrazie środkowej Polski, „Biuletyn Uniejowski” 20I9,t. 8,s. I8I-I96.https://doi.org/Io.I8778/2299-8403.08.II

Kulawiak A., Rachwał T., Smętkiewicz K., The Impact of Infrastructure, Industrial and Housing Investments on the Development of Local Systems Based on the Example of the Uniejów Commune in the Eódz Voivodeship (Poland), „Studies of the Industrial Geography Commission of the Polish Geographical Society" 2018, t. 32, nr 3, s. 69-97. https://doi. org/10.24917/20801653.323.5

Kulesza M., Rozwój przestrzenny miasta, [w:] J. Szymczak (red.), Uniejów. Dzieje miasta, Towarzystwo Przyjaciół Uniejowa, Łódź-Uniejów 1995, s. 465-490. 
Kurek K.A., Geothermal resources and local development in Poland, (niepublikowana rozprawa doktorska), Wageningen University, Wageningen 202r. Kurzyk P., Kowalski M., Popularność Uniejowa na tle matych miast regionu tódzkiego oraz konkurujacych z nim uzdrowisk, „Biuletyn Uniejowski” 2019, t. 8, s. 77-97. https://doi.org/10.18778/2299-8403.08.05

Latour T., Smętkiewicz K., Wtaściwości fizykochemiczne i chemiczne wód geotermalnych $w$ Uniejowie ze szczególnym uwzględnieniem wody zodwiertu PIG/AGH-2, „Biuletyn Uniejowski” 201 2, t. I, s. 79-93.

Lisiewska M., Rybak M., Udziat macromycetes w zespołach leśnych parku $w$ Uniejowie, „Badania Fizjograficzne nad Polską Zachodnią. Seria B” I990, t. 40, s. 5-28.

Michałowski M., Saran E., Wójcik A., Geothermal energy in Uniejów - characteristics, „Inżynieria Mineralna” 2015, nr I6, s. I27-I32.

Milewska-Osiecka K., Ogrodowczyk A., Warunki mieszkaniowe w matych miastach Polski ze szczególnym uwzględnieniem Uniejowa, „Acta Universitatis Lodziensis. Folia Geographica Socio-Oeconomica” 2015, nr I9, s. I29-I48.

Olejniczak P., Wyniki inwentaryzacji gniazd bociana białego (ciconia ciconia) w gminach: Poddębice, Uniejów, Pęczniew i Zadzim w roku 1984, „Acta Universitatis Lodziensis. Folia Zoologica" I992, nr I, s. 29-38.

Osiewalska A., Mierniki oceny czasopism i naukowców, „Biuletyn EBIB” 2008, nr 8 (99).

Piotrowska-Nosek K., The castle park in Uniejów: towards a restoration plan, „Monument: studies and materials of National Center for Historical Monument Studies and Documentation" 2005, t. I, s. 197-210.

Rozporzadzenie Ministra Nauki i Szkolnictwa Wyższego z dnia 20 września 2018 r. w sprawie dziedzin nauki i dyscyplin naukowych oraz dyscyplin artystycznych, Dz.U. 2018, poz. I8I8.

Rusin T., Analiza cytowań publikacji wydanych $w$ czasopiśmie "Folia Turistica” w latach 1990-2016, „Folia Turistica”, 2019, nr 45, s. 45-74.

Samołyk M., Maciaszczyk H., Impact of Uzdrowisko Uniejów Park (Health Resort Uniejów Park) on tourism in the neighbouring municipalities „,Geography and Tourism" 2018, t. 6, nr 2, s. 87-95.

Sapińska-Śliwa A., Udostępnianie wód termalnych $w$ Uniejowie - rys historyczny, „Biuletyn Uniejowski” 20I2, t. I, s. 63-77.

Sapińska-Śliwa A., Lewkiewicz-Małysa A., Winid B., Wody termalne Uniejowa w świetle interpretacji wskaźników hydrochemicznych, „Wiertnictwo, Nafta, Gaz” 20I I, t. 28, s. 359-369. 
Sapińska-Śliwa A., Wojnarowski P., Gonet A., Analysis of Uniejów geothermal water reservoirs modeling in view of various aspects of geothermal water and heat management, Proceedings of World Geothermal Congress 2010, 25-29 kwietnia 2010 r., Bali, Indonezja 2010.

Smyk K., Spycimierskie kwietne dywany na Boże Ciato - typologia i symbolika wzorów, „Biuletyn Uniejowski” 2019, t. 8, s. 35-65. https://doi. org/10.18778/2299-8403.08.03

Smyk K., Zmieniać rzeczy w znaki. Kod przedmiotowy w tradycji Bożego Ciata z kwietnymi dywanami w Spycimierzu, „Biuletyn Uniejowski” 2020, t. 9, s. 5-2I. https://doi.org/10.18778/2299-8403.09.0I

Stos D. (red.), Województwo konińskie: zarys dziejów, obraz wspótczesny, perspektywy rozwoju: monografia regionalna, Uniwersytet Łódzki, Łódź 1989. Suliborski A., Kunka T., Gospodarka i warunki bytowe po II wojnie światowej, [w:] J. Szymczak (red.), Uniejów. Dzieje miasta, Towarzystwo Przyjaciół Uniejowa, Łódź-Uniejów 1995, s. 361-365.

Szkutnik P., Początki tworzenia kompozycji z kwiatów na trasie procesji Bożego Ciała w Spycimierzu, „Archiwa, Biblioteki i Muzea Kościelne” 2019, t. I II, s. 33 I $^{-344}$. https://doi.org/I0.31743/abmk.6302

Szkutnik P., Pożyczka na budowe domu Franciszka i Jadwigi Gawrońskich w Uniejowie w I808 roku, „Biuletyn Uniejowski” 2017, t. 6, s. I22-I29. https://doi.org/I0.18778/2299-8403.06.08

Szkutnik P., Regionalny poradnik genealogiczny - stan zachowania ksiag metrykalnych parafii rzymskokatolickich w gminie Uniejów, „Biuletyn Uniejowski” 20I 2, t. I, s. I77-I87.

Szymczak J. (red.), Uniejów. Dzieje miasta, Towarzystwo Przyjaciół Uniejowa, Łódź-Uniejów I995, s. 19-47.

Śleszyński P., Pozycja polskich czasopism i serii geograficznych w świetle baz Google Scholar, „Przegląd Geograficzny” 2009, t. 8I, z. 4, s. 551-578. https://doi.org/I0.7163/PrzG.2009.1.6

Wiktor J., Próba analizy bibliometrycznej publikacji 25. Zjazdu Katedr Marketingu, Handlu i Konsumpcji - doświadczenia przeszłości i wyzwania przyszłości, „Zeszyty Naukowe SGGW, Polityki Europejskie, Finanse i Marketing” 2016, nr I5 (64), s. I70-I82. https://doi.org/I0.22630/ PEFIM.2016.I5.64.16

Wilk-Woś Z., Zamek arcybiskupów gnieźnieńskich w Uniejowie w XV wieku wświetle źródet pisanych, „Biuletyn Uniejowski” 2015, t. 4, s. 45-62. 
Wiluś R., Miasto i gmina Uniejów w pracach doktorskich, magisterskich i licencjackich opracowanych na Wydziale Nauk Geograficznych Uniwersytetu Łódzkiego, „Biuletyn Uniejowski” 20I 2, t. I, s. 205-2I2.

Woźniak K.P., Próba uprzemystowienia Uniejowa w latach 20-30 XIX wieku, „Biuletyn Uniejowski" 2018, t. 7, s. I7-28. https://doi.org/I0.18778/2299-8403.07.02 Wójcik T. (red.), Zapamiętane z Brückstädt. Wspomnienia wojenne mieszkańców ziemi uniejowskiej, Towarzystwo Przyjaciół Uniejowa, Uniejów 2014. Wójcik T., Boraś J., Walki oddziału wydzielonego ppłk. Mariana Frydrycha z jednostkami 30 dywizji piechoty wehrmachtu o utrzymanie przeprawy mostowej $w$ Uniejowie $w$ dn. 6-7 wrzésnia I939 roku, „Biuletyn Uniejowski” 2020 , t. 9, s. $23-57$.

\section{The position of „Biuletyn Uniejowski” on the academic publications market on its $\mathrm{IO}^{\text {th }}$ anniversary}

SUMMARY | The IO ${ }^{\text {th }}$ - anniversary - volume of "Biuletyn Uniejowski” is an occasion for some reflections on the position of this journal on the scientific publications market. This article is a kind of report comprising the whole period since its launch. The main purpose of the article to identify links between studies presented in „Biuletyn Uniejowski” and the different study areas and academic disciplines. The analysis is based on data from Google Scholar. Although nearly 50\% of the texts published in „Biuletyn Uniejowski” can be classified as belonging to social sciences, the journal maintains an interdisciplinary character, which is confirmed by the fact that its articles are cited in journals representing various fields of study: social sciences, exact and natural sciences, engineering and technology, humanities, and agriculture.

K E Y W O R D S | „Biuletyn Uniejowski”, Google Scholar, citations, parametrization, h-index, fields of study, academic disciplines, scholarly publications

| Informacje o artykule: przyjęto - maj 202I; zaakceptowano - maj 202I 
Załącznik I

Wykaz czasopism zewnętrznych cytujących artykuły z „Biuletynu Uniejowskiego” oraz matryca przyporządkowania ich do dziedzin i dyscyplin naukowych, wykorzystana w badaniach

\section{Dziedzina - nauki humanistyczne}

\begin{tabular}{c|c}
\hline Dyscyplina & Tytuł czasopisma \\
\hline archeologia & "Archaeologia Polona” \\
\hline historia & "Archiwa, Biblioteki i Muzea Kościelne” \\
& "Roczniki Humanistyczne” \\
& "Studia Lednickie” \\
& "Textus et Studia" \\
"Zeszyty Wiejskie”
\end{tabular}

Dziedzina - nauki inżynieryjno-techniczne

\begin{tabular}{|c|c|}
\hline Dyscyplina & Tytuł czasopisma \\
\hline $\begin{array}{l}\text { architektura } \\
\text { i urbanistyka }\end{array}$ & $\begin{array}{l}\text { „Przestrzeń i Forma” } \\
\text { „Topiarius. Studia krajobrazowe” }\end{array}$ \\
\hline $\begin{array}{l}\text { inżynieria lądowa } \\
\text { i transport }\end{array}$ & $\begin{array}{c}\text { „Przegląd Komunikacyjny” } \\
\text { „Transport Problems” } \\
\text { „TTS Technika Transportu Szynowego" }\end{array}$ \\
\hline $\begin{array}{l}\text { inżynieria } \\
\text { mechaniczna }\end{array}$ & $\begin{array}{c}\text { „Zeszyty Naukowe. } \\
\text { Cieplne Maszyny Przepływowe - } \\
\text { Turbomachinery / } \\
\text { Politechnika Łódzka” }\end{array}$ \\
\hline $\begin{array}{l}\text { inżynieria } \\
\text { środowiska, górnictwo } \\
\text { i energetyka }\end{array}$ & $\begin{array}{l}\text { „Energy Reports” } \\
\text { „Inżynieria Mineralna” } \\
\text { „Technologia Wody” }\end{array}$ \\
\hline
\end{tabular}

Dziedzina - nauki rolnicze

\begin{tabular}{c|c}
\hline Dyscyplina & Tytuł czasopisma \\
\hline nauki leśne & "Acta Scientiarum Polonorum. \\
& Silvarum Colendarum Ratio et Industria Lignaria” \\
"Rocznik Polskiego Towarzystwa \\
Dendrologicznego" \\
"Studia i Materiały Centrum Edukacji \\
Przyrodniczo-Leśnej"
\end{tabular}




\begin{tabular}{|c|c|}
\hline \multicolumn{2}{|r|}{ Dziedzina - nauki społeczne } \\
\hline Dyscyplina & Tytuł czasopisma \\
\hline ekonomia i finanse & „Studia Oeconomica Posnaniensia” \\
\hline nauki prawne & „Roczniki Nauk Prawnych” \\
\hline $\begin{array}{l}\text { geografia społeczno- } \\
\text {-ekonomiczna } \\
\text { i gospodarka } \\
\text { przestrzenna }\end{array}$ & 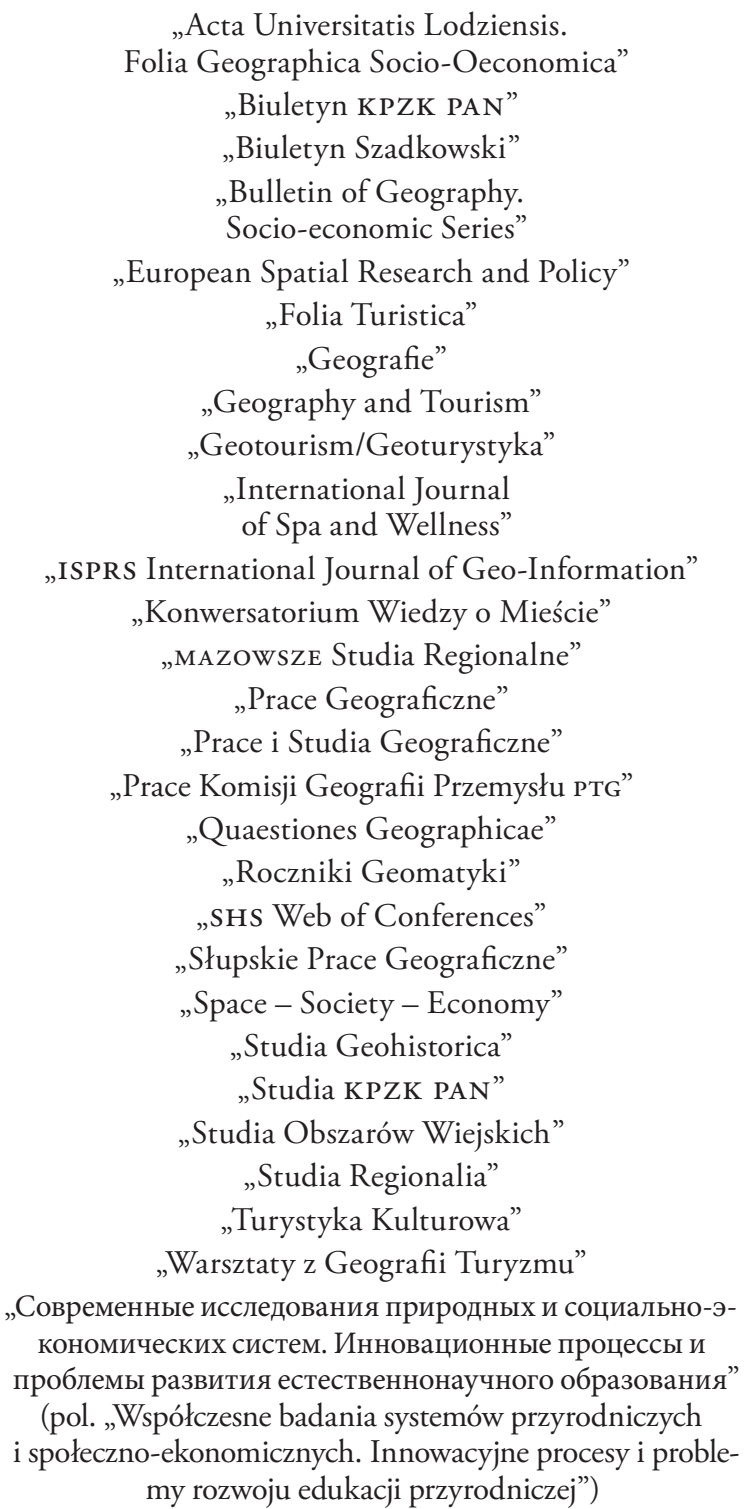 \\
\hline
\end{tabular}


Załącznik I cd.

Dziedzina - nauki ścisłe i przyrodnicze

\begin{tabular}{|c|c|}
\hline Dyscyplina & Tytuł czasopisma \\
\hline nauki biologiczne & $\begin{array}{c}\text { „Ecological Questions” } \\
\text { „Inżynieria Ekologiczna” } \\
\text { „Journal of Ecological Engineering” } \\
\text { „Steciana” }\end{array}$ \\
\hline $\begin{array}{c}\text { nauki o Ziemi } \\
\text { i środowisku }\end{array}$ & $\begin{array}{c}\text { „Acta Geographica Lodziensia” } \\
\text { "Acta Universitatis Lodziensis. } \\
\text { Folia Geographica Physica” } \\
\text { „Contemporary Trends in Geoscience" } \\
\text { „Gospodarka Wodna” } \\
\text { "Przegląd Geofizyczny" } \\
\text { „Woda - Środowisko - Obszary Wiejskie” }\end{array}$ \\
\hline
\end{tabular}

